\title{
Alterations in postmodernity: setting up Bulimia nervosa
}

\author{
Goetz Egloff \\ Research Therapist for University Hospital of Heidelberg, Heidelberg, Germany
}

Email address:

goetz.egloff@alumni.uni-heidelberg.de, sdgap-heidelberg@email.de

\section{To cite this article:}

Goetz Egloff. Alterations in Postmodernity: Setting up Bulimia Nervosa. Science Journal of Clinical Medicine.

Vol. 2, No. 6, 2013, pp. 160-165. doi: 10.11648/j.sjcm.20130206.13

\begin{abstract}
In Bulimia nervosa, a complex syndrome of clinical symptoms is formed. The patient who will mostly attempt to keep her syndrome hidden is subjected to diverse alterations that can be observed in her, her family and society. Somatic alterations in Bulimia nervosa patients are depicted, family idiosyncrasies in families with a bulimic member are highlighted. The research project on Bulimia nervosa 2007-2010 at the University of Heidelberg is outlined, leading to a pondering of psychodynamic symptom formation. Aspects of oedipality are shown in a case vignette of an 18-year-old female bulimic patient experiencing and restaging guilt and seduction issues. Some leads at mass society's influence on the way symptom formations appear today are to broaden the perspective by means of I. Hassan's cultural characteristics of modernity and postmodernity. After a close look at alterations in clinics of bulimic patients that shows how the cultural paradigm of postmodernity is reflected in the patient, Bulimia nervosa, often as a low profile phenomenon in daily gynaecologic and primary care practice, is declared requiring apt intervening in clinical treatment, and conceptualizing of human developmental processes in new ways. Psychosomatic Medicine will benefit from cross-referencing on psyche, body, and society, in order to understand psychosomatic condition even better than before.
\end{abstract}

Keywords: Bulimia Nervosa, Psychodynamics, Alterations, Postmodernity, Oedipality

\section{Somatic Alterations in Bulimia Nervosa}

A first outline of somatic alterations in Bulimia nervosa (1) is to highlight the somatic phenomena that can be observed in bulimic patients. In inspection, they often show lanugo hair, alopecia, swollen salivary glands, dental caries, and sores on fingers or lesions on the back of the hand caused by repetitive cramming fingers down the throat in order to purge. Laboratory data often show hypocaliemia, transaminasis, amylasis, and urinary substances, also alterations in lipid metabolism, decrease of total protein and albuminum as well as lack of zinc. Endocrinology parameters often show disorders of hypothalamic hypophyseal axes: pituitary adrenal axis (increase of CRF and cortisol), pituitary thyroid axis (TSH and T4 normal or decreased, T3 decreased), pituitary gonadal axis (FSH, LH, and estradiol decreased), increase of growth hormone, and decrease of leptin. Other alterations may show in CT and MRT (pseudoatrophia cerebri), esophagitis, ECG, hypotonia, bradycardia, and osteoporosis. Complications caused by laxative abuse like osteomalacia and malabsorption syndrome may go along with severe obstipation and hypertrophic osteoarthropathia.

These are somatic issues the patient may have to deal with. What are the psychic issues, the psychic alterations? What is known of their origin as to these mostly adolescent patients?

\section{Alterations in Family Interaction}

The common alterations in interactional patterns of families with a member with eating disorder have been depicted distinctively (2). Central issues are, from a family dynamics point of view: conflicts, impulses, resonance, infringements, secrets, stimulation. The very way how these issues are dealt with are not only different from average families but from those with an anorectic member: families with an anorectic member deal with their conflicts in a more hidden way, whereas families with a bulimic member deal with their conflicts in a more open way, have a higher level of impulsive acting out, show toned down affective resonance, have more open assaults on privacy, and more family secrets. Potentially sexually stimulating issues are forced in these families. In families with an anorectic member conflicts are rather suppressed, acting out of impulses is rather inhibited, affective resonance is rather shown, infringements are kept hidden, secrets seem less 
relevant, and sexually stimulating issues are rather inhibited. Families in a bulimic mode tend to act out, this not only being relevant for the bulimic member but for all family members. Generally, bulimic families live up to the motto: Act, don't neglect! (2). Probably in order to keep anxiety low, the anorectic mode bears rather a restrictive attitude; instead, the bulimic mode bears rather a pseudo-autonomous, loose attitude in order to defend wishes. It is not quite clear whether these attitudes are fed by intrapsychic dynamics of individuation issues, and/or autarky issues, or else. From a Lacanian point of view, the structural triad (3) is constituted as early as conceivable, so that Ego-psychological concepts alone do not tally. Yet, from a pragmatic point of view, it seems adequate to look at intrapsychic conflicts that way.

\section{Alterations in Psyche}

In earlier publications, different authors such as Gress (4), Seidler (5), Greenson (6), and Egloff (7) have pointed at the fact that, according to the respective kind of disorder, classic concepts of psychoanalysis like hysteria, also recent psychodynamic concepts (8) (9) as well as systemic and family dynamics approaches of communication disorders (10) (2) (11) (12) (13) can be applied in a sensible way. The first may reasonably be useful concerning etiopathogenetics, the latter in maintaining the syndrome. Any kind of hysteriform syndrome does not necessarily have to be core hysteria. Additionally, very differing syndromes may be core hysterias, according to Greenson (6), coming in disguise. From a psychodynamic viewpoint, symptoms emerge from conflict formations that collide within the individual. In that sense, psychoanalytic, and with that, psychodynamic theory in general is grounded in psychological determinism which means that symptoms make sense. This has been the case with Bulimia nervosa, too. While from a family dynamics oriented perspective, a systemic and structural-functional aspect is in focus, in psychodynamic thinking one will look for urges, wishes and relation formations that make for the necessity of forming symptoms. The therapeutic aim is to make them superfluous, to dissolve that necessity. Intrapsychic conflict formations exist in Bulimia nervosa as well (2). With such conflict formations, emotions and affects go along. With that, in classic modern perspective, affects of shame and of guilt regularly appear as a result of conflicts. Not only clinical syndromes, but human development in itself is a phenomenon consisting of the above mentioned emotions and affects regularly. Yet, it is also the result of early stress experiences as well as of the socio-cultural conditions that the subject lives in. The enormous societal changes that took place within the last century have brought up mass culture and mass media. It is significant that in human development there are analogies to contemporary societal development and vice versa. This fact seems not to have been focused on too much. Instead, the way society is by now seems to be taken as the only way it can be. Yet, the central topos of subjective guilt in the psychoanalytic concept of oedipality still seems to be seminal in Bulimia nervosa, whereas pre-oedipal conflicts, or structural deficits, may play an additional role in etiopathogenetics. Here is a highlight of how modes of guilt and seduction in oedipality may appear.

\section{Case Vignette}

The 18-year old female patient is used to pulling her mother to pieces, while idolizing, almost deifying her father. Her experiencing of men in general carries this tone of idolization. Without choosing a lot, she will get intimate with men she finds attractive. My interpretation of her searching for a relationship with her father who sleeps with her mother instead of with her, outrages the patient first, then makes her show contrition. The oedipal attempt of competing with her mother is of no avail but forming feelings of guilt and shame within the patient. Regularly, she cannot bear these feelings; so to get rid of them, she admits to throw feelings like these out of her, to puke them out. This is quite often the case in Bulimia (14); relief of this mechanism regularly will take place after the inner acceptance of this issue. The patient's Ego will have to be strengthened enormously, so that amorphous imagines, impulses and introjections can at least be abided and controlled. From a psychoanalytic perspective, this seems to be an issue in any human development.

Towards the end of therapy, the patient will be able to do better and better. The repetition compulsion of oedipal guilt and seduction did not only show in the symptom, but in this case in restaging that topic exactly by means of her accidentally dropping her wide swinging ethno skirt when leaving the therapy room. Giving sight of her buttocks, as it were, mooning to the therapist, is to be understood as debasement of the therapist and as a gesture of sexual seduction at the same time. Yet, the seductive gesture is externalized. Immediately with the patient's insight into the contents of the session, the emotional defense emerges as repetition compulsion, producing an image of seduction. Yet, the debasement gesture is equally important as an externalization of shame and guilt toward the therapist, since the eroticized transference is only showing on a toned down level. Resistance on such a bland level - in contrast to any higher level - makes a process of working through possible; this being something that is not regularly the case in patients (6).

\section{Research Project on Bulimia Nervosa}

Now being in its final evaluation phase, in the research project on „Bulimia nervosa in adolescent Girls and young Women“ („Forschungsprojekt zur Bulimia nervosa bei jugendlichen Maedchen und jungen Frauen") which was conducted from 2007 to 2010 at the University Hospitals Heidelberg and Goettingen, Germany, the issue of oedipality will have to be taken under close consideration. By now there have been explorations as to the aspect of shame in bulimic patients (15), and as to dysfunctional family 
relational patterns (16).

The study was designed as a randomized controlled therapy study (RCT), the cohort consisting of 60 female outpatients with F 50.2 Bulimia nervosa (ICD-10), and 40 female outpatients with F 50.3 atypical Bulimia nervosa (ICD-10). Structural deficits were also diagnosed, as well as specific personality characteristics were examined. Anamnestic and catamnestic evaluation took place (six and twelve months after ending), so were interviews conducted after 30 and 45 sessions. The 60 -sessions-setting, conducted in a frequency of one to two hours per week, led to total therapy duration of one to one and a half years. In the opening phase of psychodynamic therapy, disorder oriented diagnostics took place (Central Relational Conflict Issue) (17). In the so-called treatment phase, the central issues (foci) relation, conflict, and structure of the patient had to be worked through psychodynamically, sticking as well as close to the symptoms as to the aims of therapy (17) (9). In the ending phase, those aims were being evaluated with the patient as to transforming insights into her real life. As far as first results have been anticipated, the effectiveness of psychodynamic psychotherapy will be highly probable. The study manual is now being modified into a manual for different therapy approaches which will be published shortly.

Most studies in Bulimia nervosa have been quantitatively oriented. Researchers in biological psychiatry tend to look for metabolism disorders or behavioral patterns that are easy to access and to operationalize. This certainly is an important aspect, yet it sometimes gets in the way of taking a profound look at biographical and societal aspects in the genetics of psychic und psychosomatic disorders (4). This may not be intentional, still it is due to the separation of academic subjects. This cannot be further discussed here; Fischer (18), and regularly Pritz (19) (20) have published on this issue. What about the societal implications going along with postmodern symptom formation?

\section{Alterations in Society: Hassan's Characteristics of Modernity and Postmodernity}

In order to illustrate the change in symptom formation apart from intrapsychic conflicts alone, I. Hassan's chart of characteristics of modern and postmodern features (21) is to be drawn upon. Originally stemming from cultural sciences, Hassan's chart can show that, in a clinical context, cultural symptoms form within the individual. Clinical symptoms not only constitute in transference and relational processes, but also within the socio-cultural mentality and devise from which they emerge and which they constitute (22) (23). Psychic development today is different from the development one hundred years ago, and it is different from the one one thousand years ago, as is society itself. As a marker in the text there will be a $(\mathrm{m})$ for a feature of modernity, a (pm) for a feature of postmodernity.

\subsection{Aspects of Form}

One pair of Hassan's characteristics from modernity to postmodernity is the replacement of Romanticism and Symbolism (m) by Pataphysics and Dadaism (pm). Romanticism and Symbolism gave way to the foundations of psychoanalysis and the concept of the unconscious. Pataphysics as metaphysics behind metaphysics query the modern concept, Dadaism in its playing with making sense sidesteps lines of sense, leading them ad absurdum. With that, Irony (pm) replaces Metaphysics (m), drafting on set pieces of sense and symbol in forming symptoms. Symbolized conflicts instead, in a clinical context, tend to be recognized only in traces anymore; rather open and disjunctive anti-forms (pm) emerge not only in clinical populations. Closed and conjunctive forms (m) of symptom formation, so-called neurotic in classic developmental psychodynamics, in its main affect, anxiety, tend to be recognized less and less. The latter, being the rule one hundred years ago, have come to be the exception from the rule today, whereas the former exception has come to be the rule today. Purpose $(\mathrm{m})$ in the teleological sense of personal development, meaning becoming a subject, overcoming tribulations (cp. the works of Freud, Rank, Rogers), is rather transformed into Play ( $\mathrm{pm})$, be it a play of life, play of language, play of identities (cp. the works of Wittgenstein, Goffman). Parts of identity, behavior, and experiencing have become set pieces (cp. the works of Bruder-Bezzel, Langendorf) of an undetermined experiencing of developmental processes which seem to be void of making at least subjective sense.

Design (m) and Chance (pm) go along analogously with that, just like Hierarchy $(\mathrm{m})$ as experiencing and forming of order and structures, in contrast to Anarchy (pm) as experiencing and forming of dissolution and absence of order and structures, seems to be set apart. Distance (m) and Participation (pm) can be seen quite similarly: privacy, reflection, and meaning give way to acting out, to public exposing, and to any given stimulation.

\subsection{Aspects of Language}

The Signified (m) as a reference is still present in modernity; it provides representation. The classic concept of signal anxiety (24) as signal of anticipated tension refers to that concept, assuming there is something behind something. In postmodernity this concept is substituted with the Signifier (pm), a run of sounds that have no reference. Here, phonemes are strung together forming parole (25), referring to nothing beyond parole itself. Conflicts as well as displaced conflicts, under the reign of the Signifier, cannot be represented and with that do not exist; only symptoms remain referring to nothing.

The pair Synthesis (m) and Antithesis (pm) hint at the kind of distortion that lies within postmodernity. While the linear formula of thesis and antithesis has led to synthesis of thought and language, synthesis itself by now gives way to new superordination, to a new hyperonym: antithesis as a 
step beyond synthesis, turning down any linear dialectics but defining a new unquestionable space of argument. This is what seems to be so crucial in postmodernity. The pair Presence (m) and Absence (pm) seem to describe that process itself, as do Centering (m) and Dispersal (pm); these pairs reflect the relation between classic conflict formation in neurosis and fragmentation of psychic structure. What B. Rank (26) once described as different levels in Ego functions that are to be developed, has transformed into structural fragmentation, as in early pre-oedipal, psychosis-like symptoms taking over, forming amorphous amounts of distortion and eeriness like often reported by bulimic patients. Genre, Limit (m) and Text, Intertext (pm) point at a change from limitation, disaffirmation, and reproof (clinical: assaults on privacy like intrafamiliar reading of a member's diary, among other infringements), to delimitation, generational enmeshment, patchwork, and emotional entanglement. This tendency has been extensively explored in clinical family dynamics research. Classic psychodynamics will benefit from these observations, as the inner digestion of this development shapes the subject in postmodernity. The pairs Semantics (m) and Rhetorics (pm), Paradigm (m) and Syntagm (pm), Hypotaxis (m) and Parataxis (pm), Selection (m) and Combination (pm); Root, Depth (m) and Rhizome (cp. the works of Lyotard), Surface (pm), as well as Interpretation, Reading (m), and Counter-Interpretation, Misreading (pm) can be viewed similarly. Moreover, the growing disappearance of similarity in Metaphor $(\mathrm{m})$ favors more and more association in Metonymy (pm).

\subsection{Clinical Aspects}

Mastering and Logos (m) have given way to Exhaustion and Silence (pm), and Art, Object and Finished Work (m) have lost their impact in favor of Process, Performance and Happening (pm). On an individual developmental level, this goes along with processual and potentially creative approaches for the subject (27), bearing great opportunities of freedom of development, (self-)invention (28), and therapeutic reasoning (29), on the other hand there has been an increasing imperative of permanent self-invention and, with that, non-fulfillment which has come to be a societal symptom of today (30) (7). Creation, Totalization (m), and Decreation, Deconstruction (pm) seem to point at this, although Creation is not to be confused with creativity. Instead, Creation belongs to the modern epoch of establishing new structures, new ways of life, new meanings; Decreation is the result that is yielded by those processes, it is the answer to the questions that were or were not asked. After any radical societal changes have been induced and dispatched, what remains is repetition - even as repetition of fiction. Everyday acts of ordinary life may be recharged creatively, still there will be a phantasmagoric character to drafting on existing scripts that seems to make any inner minutes second hand. By this, any authoring of subjective Narrative (m) will not be understandable, thus becoming an Anti-Narrative, a Petite Histoire (pm), contrary to any old-fashioned Grand Histoire (m) which is based on Narratives. A decipherable Master Code (m) gives way to an undecipherable Idiolect (pm) reverberating with a permanent barrier of talking at cross purposes.

The pair Lisible, Readerly (m) and Scriptible, Writerly (pm) stems from Barthes (31) who puts Plaisir (joy, enjoyment) in opposition to Jouissance (lust, orgasm). The first has a rather accessible quality that can be understood by logos. Jouissance, instead, touches depths of experiencing that cannot be understood but only experienced in Id-quality. Along with this, a Symptom (m) as expression of neurosis in modernity gives way to symptoms of Desire and Delusion (pm) in postmodernity. The latter is much more powerful than the first: intrapsychic conflicts give way to delusion, a delusion that manifests itself in a hardly-to-be-soothed fashion. It is highly questionable if this is correctable by overcoming barriers of subjectivity, bearing in mind that intersubjectivity in therapy does not necessarily reach the issues at stake.

Lukács conceptualized the topos of searching in mankind (32); a searching that has been linked to the main affect of anxiety. In its facets, be it clinically generalized, be it developmental fear, anxiety seems to be substituted with some universal allergy against any definitive order (cp. the works of Baudrillard), against definition. In Bulimia nervosa, this allergy seems to manifest itself extensively. Escapism may be the hallmark of it. It leaves Paranoia (m) as main mode of the Cold War era behind in favor of Schizophrenia (pm) as polyphonia of the dispersal of emotion and reasoning and as loss of naturalness, as loss of matter of course (cp. the works of Blankenburg).

Cause and Origin (m) get replaced by Difference/Differance (cp. the works of Derrida) and Trace (pm), thus replacing diachronic, linear-causal thinking by synchronic adjoining each other and by de-centered exploitation. Any Type (m) may thus be replaced by a Mutant (pm) that evades, balks at the concept of Genital, Phallic (m). Instead, a Polymorphous, Androgynous (pm) shape of phenomenon will appear, not only in Bulimia nervosa quite a fitting idea but a concept of going beyond Defining Scene. God the Father (m) and The Holy Ghost (pm) in Hassan's nomenclature arise from the decline of the principle of origin, mother, father, in favor of a dematerialized displacement going nowhere, like assisted reproduction in its psychological extremes (33). A change from Determinacy $(\mathrm{m})$ to Indeterminacy $(\mathrm{pm})$ forbids any Transcendence ( $\mathrm{m})$, and Immanence (pm), as self-referential, takes place instead. On an existential level, there remains nothing left to recognize, and nothing left to understand.

\section{Conclusion}

For clinical psychosomatics, and especially for psychoanalytic and psychodynamic therapies, it might be useful to take a closer look at societal development in order to conceptualize human development and symptom formation in an apt way. Also modified therapies - be they 
disorder-oriented, manual-oriented - will have to reflect on pharmacologic interactions, psychic interactions, and societal interactions cross-referencing on each other. Symptom formation by definition in postmodernity has undergone severe changes. Modifications of concepts will have to be pondered at any rate, as psychosomatic medicine will have to face individual and societal changes. The field is now open as to new interventions and new conceptualizations. Yet, any constructivistic approach will have to respect the intrapsychic reality of the individual and still has to consider the erosion of the societal condition (cp. the works of J. Habermas) that people live in.

In Bulimia nervosa as well as in other psychosomatic disorders, Ego-psychological intervening while e.g. allowing for the structural triad (3) may have to be seminal. Analytic and systemic intervening at the same time may be a promising approach in psychosomatic medicine (34) (35) (36). Behavioral intervening may always be useful (37), provided that it is embedded in a biographic concept of human development (11) (7). Additional medication like Selective Serotonin Reuptake Inhibitors (SSRI) as well as prescription of an oral contraceptive (38) may be useful and may have to be given a try at least. However, the patient is and will be subjected to societal relations and to the societal devise she has grown up in.

\section{Acknowledgment}

The author wishes to thank the International Society of Psychosomatic Obstetrics and Gynaecology (ISPOG) for inviting this paper to be presented at the 17. International ISPOG Congress, The Brain - The Body - The Society, Berlin, Germany, May $23^{\text {rd }}$ to $25^{\text {th }}, 2013$.

\section{References}

[1] Herpertz-Dahlmann B, Resch F, Schulte-Markwort M, Warnke A (2008). Entwicklungspsychiatrie. [(Developmental Psychiatry.) (In German)] Stuttgart: Schattauer.

[2] Reich G, Cierpka M (1997). Psychotherapie der Essstoerungen. [(Psychotherapy of Eating Disorders.) (In German)] Stuttgart: Thieme.

[3] Lang H (2011). Die strukturale Triade und die Entstehung frueher Stoerungen. [(The Structural Triad and the Origin of Psychic Disorders.) (In German)] Stuttgart: Klett-Cotta.

[4] Gress H (2001). Ueber die soziale Botschaft der Hysterie. (On the social Message of Hysteria.) In: Seidler, Hysterie heute.

[5] Seidler G (editor) (2001). Hysterie heute. [(Hysteria today.) (In German)] Giessen: Psychosozial.

[6] Greenson RR (2007). Technik und Praxis der Psychoanalyse. [(The Technique and Practice of Psychoanalysis.) (In German)] Stuttgart: Klett-Cotta.

[7] Egloff G (2012a). Objektbeziehung und Performanz. Zur relationalen Dynamik der Libido. [(Object relations and Performance - on the Relational Dynamics of the Libido.) (In German with English abstract)] Prax Kinderpsychol Kinderpsychiatr 61: 497-511.

[8] Reich G (2002). „Defektes Selbst“ - „Defekter Körper“. Destruktiver Narzissmus bei der Bulimie. [(,Faulty Self" „Faulty Body“. Destructive Narcissism in Bulimia.) (In German)] In: Seidler G (editor) (2002). Das Ich und das Fremde. [(The Ego and the Foreign.) (In German)] Giessen: Psychosozial.

[9] Arbeitskreis OPD (2006). Operationalisierte Psychodynamische Diagnostik OPD-2. [(Operationalized Psychodynamic Diagnostics OPD-2.) (In German)] Bern, Goettingen: Hans Huber.

[10] Groene M (1995). Wie lasse ich meine Bulimie verhungern? [(On how to let your Bulimia starve.) (In German)] Heidelberg: Carl Auer.

[11] Egloff G (2010a). The Unknown in Our Biography. (Review on Marianne Kruell, Birth is not the Beginning.) Int J Prenat Perinat Psychol Medicine 22: 164-166.

[12] Egloff G (2010b). Familientherapie ohne Familie. Systemische Kurzzeittherapie mit einer 38-jaehrigen Mutter als Indexpatientin. [(Family Therapy without Family. Systemic Short Term Therapy with a 38-year-old Mother as Index Patient) (In German with English Abstract)] KONTEXT 41: 200-209.

[13] Egloff G, Becker B (2011). Defizit- und Loesungsorientierung in der systemischen Psychotherapie. Chancen und Gefahren am Beispiel der Einzeltherapie eines 32-jaehrigen Patienten mit depressiven und aggressiven Tendenzen. [(Deficit Orientation and Solution Orientation in Systemic Psychotherapy. Risks and Chances in the Therapy Process of a 32-year-old male Patient with depressive and aggressive Tendencies) (In German)] CoMed 17 (3): 66-69.

[14] Egloff G (2009). Die Tuecken der bulimischen Beziehung. Therapiewunsch einer 23-jaehrigen Patientin mit Bulimia nervosa. [(Trapped in a Bulimic Relational Pattern. A 23-year-old female bulimic Patient imagining Therapy.) (In German)] Freie Psychotherapie 9 (4): 18-19.

[15] Frost U, Strack M, Reich G, Kronmueller K, Stefini A (2010). Die Rolle der Scham in den Familienbeziehungen bulimischer Patientinnen. (The Role of Shame in the Family Relations of bulimic Patients.) Presentation at the Congress for Eating Disorders, Alpbach, Austria, October 2010.

[16] Frost U, Kronmueller K, Rutz U, Strack M, Reich G (2011). Zum Zusammenhang von dysfunktionalen Familienbeziehungen und Scham bei bulimischen Patientinnen. (On the Connections of dysfunctional Family Relations and Shame in bulimic Patients.) Poster Presentation at the 62.Conference of the Deutsches Kollegium für Psychosomatische Medizin (DKPM), Essen, Germany, March 2011.

[17] Luborsky L (1995). Einfuehrung in die analytische Psychotherapie. [(Introduction to analytic Psychotherapy.) (In German)] Goettingen: Vandenhoeck \& Ruprecht.

[18] Fischer G (2011). Psychotherapiewissenschaft. [(The Science of Psychotherapy.) (In German)] Giessen: Psychosozial.

[19] Pritz A (1996). Psychotherapie - eine neue Wissenschaft vom Menschen. [(Psychotherapy - a new Human Science.) (In 
German)] Vienna: Springer.

[20] Pritz A (2012). The Struggle for Legal Recognition of the Education of Psychotherapy and an autonomous Psychotherapy Profession in Europe. Int J Psychotherapy 16 (3): 65-77.

[21] Hassan I (1987). Toward a Concept of Postmodernism. In: The Postmodern Turn. Essays in Postmodern Theory and Culture. Columbus: Ohio State University Press, 91-92.

[22] Habermas T (1990). Heisshunger. Historische Bedingungen der Bulimia nervosa. [(Having the munchies. Historical conditions of Bulimia nervosa.) (In German)] Frankfurt: Fischer.

[23] Egloff G (2004). Die psychogenetische Geschichtstheorie von Lloyd deMause. [(The psychogenetic Theory of History by Lloyd deMause.) (In German)] Conference Presentation at the Dpt. Psychosomatische Kooperationsforschung und Familientherapie at the Psychosomatic Clinic of University of Heidelberg, June 2004.

[24] Freud S (1926). Hemmung, Symptom und Angst. (Inhibitions, Symptoms and Anxiety.) GW, Bd. XIV. Frankfurt: Fischer.

[25] De Saussure F (1974). Cours de linguistique générale. Wiesbaden: Harrassowitz.

[26] Rank B (1949). Aggression. The Psychoanalytic Study of the Child 3-4.

[27] Fischer-Lichte E (2004). Aesthetik des Performativen. [(Aesthetics of the Performative.) (In German)] Frankfurt: Suhrkamp.

[28] Finkelstein J (2007). The Art of Self Invention. Image and Identity in Popular Visual Culture. London, New York: I.B.Tauris.

[29] Pflichthofer D (2008). Spielraeume des Erlebens. Performanz und Verwandlung in der Psychoanalyse. [(Playgrounds of Experiencing. Performance and Transformation in Psychoanalysis.) (In German)] Giessen: Psychosozial.
[30] Reckwitz A (2012). Die Erfindung der Kreativitaet. Zum Prozess gesellschaftlicher Aesthetisierung. [(The Invention of Creativity.) (In German)] Frankfurt: Suhrkamp.

[31] Barthes R (1973). Le plaisir du texte. [(The Joy of the Text.) (In French)] Paris: Editions du Seuil.

[32] Lukács G (1984). Die Theorie des Romans. Ein geschichtsphilosophischer Versuch ueber die Formen der großen Epik. [(The Theory of the Novel.) (In German)] Munich: DTV.

[33] Berkel I (2012). Naehe Verbot Ordnung. Genealogische Nachrichten. [(Closeness Ban Order. Genealogical News.) (In German)] Giessen: Psychosozial.

[34] Fuerstenau P (1994). Entwicklungsfoerderung durch Therapie. Grundlagen psychoanalytisch-systemischer Psychotherapie. [(Promoting Developmental Processes by Therapy. Foundations of psychoanalytic-systemic Psychotherapy.) (In German)] Munich: Pfeiffer, 64-75.

[35] Egloff G (2012b). Psychodynamische Psychotherapie: Die Irrationalitaet durchdringen. [(Psychodynamic Psychotherapy: Permeating Irrationality.) (In German)] Dtsch Aerztebl PP 11: 358-360.

[36] Egloff G (2013). Wirklichkeiten und Moeglichkeiten analytisch-systemische Therapie einer 25 -jaehrigen Klientin mit sexueller Funktionsstoerung. [(Realities and Possibilities - Analytic-systemic Therapy of a 25 -year-old female Client with Sexual Function Disorder.) (In German with English abstract)] KONTEXT 44: 136-46.

[37] Salbach Andrae H, Pfeiffer E (2011). Behandlung der Bulimia nervosa. [(Treatment of Bulimia nervosa.) (In German with English abstract)] Nervenarzt 82: 1118-1124.

[38] Naessén S, Carlstroem K, Bystroem B, Pierre Y, Hirschberg AL (2007). Effects of an antiandrogenic Oral Contraceptive on Appetite and Eating Behavior in Bulimic Women. Psychoneuroendocrinology 32: 548-54. 